\title{
An empirical analysis of transport infrastructure investment and economic growth in Nigeria
}

\author{
Oyesiku Kayode $^{1}$, Onakoya, Adegbemi Babatunde ${ }^{2}$, Folawewo Abiodun ${ }^{3}$ \\ ${ }^{1}$ Centre for Transport Studies, Olabisi Onabanjo University, PMB 2002, Ago-Iwoye, Nigeria \\ ${ }^{2}$ Department of Economics, Tai Solarin University of Education, Ijebu-Ode, Nigeria \\ ${ }^{3}$ Department of Economics, University of Ibadan, Nigeria
}

\section{Email address:}

kayoyesiku@yahoo.com(Oyesiku, K.), adegbemionakoya@yahoo.com(Onakoya, A. B.), afolawewo2001@yahoo.com(Folawewo, A. O.)

To cite this article:

Oyesiku Kayode, Onakoya, Adegbemi Babatunde, Folawewo Abiodun. An Empirical Analysis of Transport Infrastructure Investment and Economic Growth in Nigeria. Social Sciences. Vol. 2, No. 6, 2013, pp. 179-188. doi: 10.11648/j.ss.20130206.12

\begin{abstract}
The paper investigated the impact of public sector investment in transport on economic growth, using Nigeria as a case study. The empirical model for the study was developed from the endogenous growth framework in which transport investment entered into the production function as input, using the Ordinary Least Squares (OLS) estimation technique and time series properties tests conducted on variables. Data for the study covered from 1977 to 2009 . The findings showed that transportation played an insignificant role in the determination of economic growth in Nigeria. An increase in public funding and complete overhauling of the transportation system in the country are suggested.
\end{abstract}

Keywords: Infrastructure, Investment, Transport, Economic Growth

\section{Introduction}

Earlier thought of investment was considered as the adjustment from a given level of capital that plays a crucial role in the models of economic growth and it is an essential component of aggregate demand that also has considerable effect on economic activities both in the short and the long run [1] and [2]. The benefits and importance of infrastructure to economic growth have been recognized for a long time. Recent literature is also replete with studies on the role of public and private investment and their impact on economic growth. Both public and private investment have been shown to have a positive impact on economic growth in long run, but in the short run only the private investment has a significant relationship with growth [3], [4], [5] and [6]. Reference [7] in particular argued that much of the decline in productivity in the United States of America (U.S.A) and other industrial countries that occurred in the 1970s was precipitated by dwindling rates of public capital investment, particularly in highway and other transportation infrastructure. This further posits investment analysis as an impetus for empirical research into the relationship between economic growth and infrastructure.

Reference [8] identified two schools of thought with respect to the link between infrastructure and economic growth. Firstly, the Keynesian school starts with the notion that any income or infrastructure can only be generated by economic growth itself in the first place. On the other hand, the Neo-Classical approach treats infrastructure as a production factor in the same style as labour and capital, as embedded within the Endogenous Growth Theory. However, the discussion on the link between infrastructure and economic growth is far from being conclusive. A number of prominent authors have argued that this link is weak or nonexistent, and the question as to whether infrastructure should be given preference in public investment decisions remains a controversial one [9].

Good transportation infrastructure is essential in economic development. It promotes factor mobility and reduces trade costs. In addition, it promotes market integration, thereby providing avenue for the reduction of price volatility and reallocation of resources in line with comparative advantage. Investments in transportation infrastructure can also influence the productive capacity through its use as a direct input in the production process thereby increasing such resources. For example, a newly constructed road allows goods to be transported to market quicker thereby reducing the total cost of production and transportation. On the other hand, transportation infrastructure may affect economic output by changing aggregate demand through the creation and increased demand for intermediate inputs from other sectors with 
concomitant multiplier effects in the economy. Such infrastructure can also indirectly enhance the productivity of existing resources. Furthermore, it can lead to "agglomeration effect" which is the magnetic or catalytic pull or attraction of resources from other regions to the area of infrastructural development by lowering production and distribution costs, stimulating private investments, improving labour productivity and engendering technological innovations. In the light of the considered effect of transportation infrastructure on economic growth, there is the need to empirically examine whether transportation capital causes economic growth causality in the Nigerian case.

Earlier macro-econometric studies on the roles of public infrastructure investments in economic growth, mostly from the developed countries have adopted aggregate time series. Reference [7] expanded the conventional production function to include the public capital or its components while [10] also utilized Cobb-Douglas production function with an assumption of constant return to scale across all inputs. However, serious methodological problems often beset such analysis as spurious correlation (non-stationarity) is usually manifested. Attempts at correcting the non-stationarity problem by first differencing of time series data runs the danger of focusing on the short run relationship between and among the series. Reference [11] opined that time series data are not very useful for examining the effects of public capital because there is insufficient variation in the data and argued that first-differencing destroys any long-term relationship.

Another approach that has been proposed for examining infrastructure is the growth nexus. This is the use of cost function method which avoids the problem of multi-collinearity that may result in estimated coefficient biases since multi-collinearity is usually more of a problem with input quantities than with factor prices. The causality problem, which is also difficult to overcome in the production function approach, does not arise in the cost function methodology because the prices of inputs rather than their quantities are exogenous. However, [12] posited that cost functions require the assumption of an optimal mix of inputs which is more plausible for applications to individual firms opted a (micro data) than to aggregate or even industry-level data.

Our approach in this study is the use of a variant of augmented Solow model econometric framework employed by [13] to investigate the relationship between transport infrastructure investment and economic growth in developing countries using Nigeria as the case study. We decomposed capital investment into three types, namely private capital, transport and other public capital investment. We are interested in investigating the determinants of growth, that is, how much of growth over some period is due to increases in various factors of production and how much stems from other forces. Growth accounting which was pioneered by [14] and [15], provides a basis for exploring the issue.
The rest of the paper is organized as follows: Section 2 provides an overview of transport infrastructure investment in Nigeria. In section 3 a review of the literature encompassing theoretical, empirical and methodological issues on infrastructure and growth is provided. Section 4 focuses on the analytical framework, the specification of the empirical model, discussion on data sources and estimation and discussion of results. The final section, section 5 provides a conclusion to the paper.

\section{Overview of Transport Infrastructure Investment in Nigeria}

Without doubt, transport has a potentially important development stimulus as it assists in interregional spread of economic activities within the country, as well as in geographical variations in unemployment, income and migration. Nevertheless, transport investment and growth along with economic development are a complex process, particularly in developing countries like Nigeria. Reference [16]. They further argued that the links between transport systems and investment in developing countries are different from those of industrialised nations, because of transport infrastructure shortage in developing countries and therefore transport investment [16, pp.264). In most developing countries, transport investment forms a major component of the capital formation as public expenditure on transportation is usually the largest single item (up to 40\%) in national budget. It is against this background that the overview of transport infrastructure investment in Nigeria is imperative, starting with highlight of the various transport modes in the country.

\subsection{Trend in Transport Infrastructure Investment in Nigeria}

Table 1: Percentage Share of Planned Public Sector Expenditure on Transport Sector 1962-1998

\begin{tabular}{lll}
\hline Plan & Plan Period & $\begin{array}{l}\text { \% Share of the } \\
\text { Transport } \\
\text { Sector }\end{array}$ \\
\hline First NationalDevelopment plan & $1962-1968$ & 21.3 \\
Second National Devt Plan & $1970-1974$ & 23.7 \\
Third National Development Plan & $1975-1980$ & 22.2 \\
Fourth National Devt. Plan & $1981-1985$ & 15.2 \\
First National Rolling Plan & $1990-1993$ & 11.6 \\
Second National Rollinf Plan & $1994-1996$ & 8.6 \\
Third National Rolling Plan & $1996-1998$ & 10.1 \\
\hline
\end{tabular}

Source: Onokala, 2012 [17]

Following the independence of the country in 1960, investment in transport consumed a significant portion of available public capital expenditure, particularly in the first 25 years. Table 1 shows the proportion of allocation to the transport sector in relation to the total planned public sector expenditure between 1962 and 1998. Within the first 25 
years of the nation's development plan period, the percentage share of the transport sector was between $15.2 \%$ and $27 \%$. However, the magnitude of the actual investment declined to $11.6 \%$ in 1990 and further to $8.6 \%$ in 1996 .

In terms of public sector capital expenditure between 1986 and 2007 (the period that data was available), capital investment in the transport sector had increased tremendously over time in absolute terms. For example, the magnitude of transport investment rose from N516 million to N19.241billion and reached a peak of N35.23 billion in year 2007 (see Figure 1).

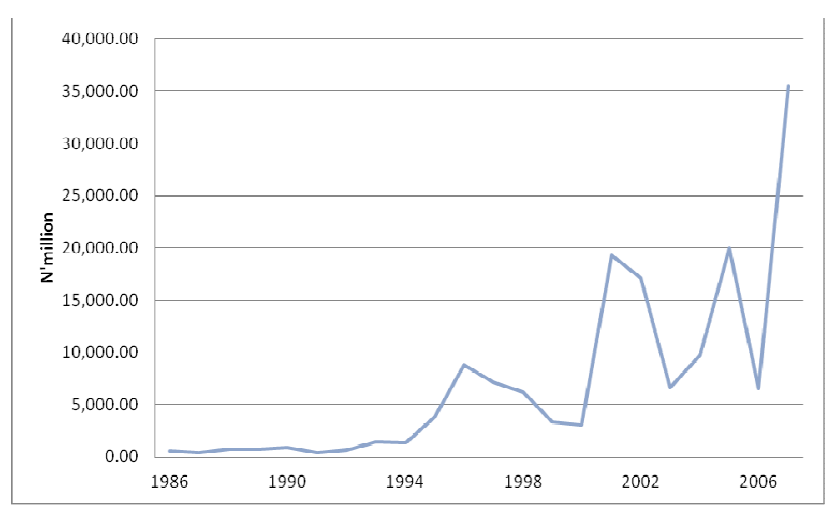

Source: National Bureau of Statistics (2010) [18]

Figure. 1: Transport and Communication Component of Government Total Capital Expenditure $1986-2007$

However, the percentage share of the transport sector in the total capital expenditure oscillated during the period under consideration, though in a state of flux but on downward trend. For instance, it was about $6 \%$ in 1986 , rose to a peak of $8.4 \%$ in 1988 and was at the lowest ever of about $0.7 \%$ in 1999 and since then, continues to fluctuate to about 5\% in 2007 (see figure 2).

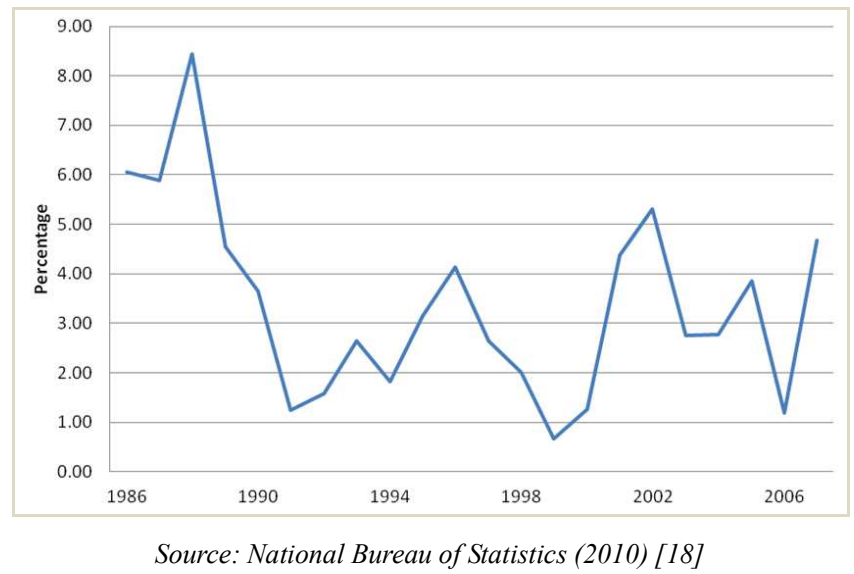

Figure. 2: Transport as Percentage of Federal Government Total Capital Expenditure 1986- 2007

It may also be of interest to compare transport capital expenditure with other components of the economic and social infrastructure sector. It's observed that transport sector performed well below agriculture, defence and education. When the average of each of the five components is compared over the period of 1986 and 2000, transport was second to the last and barely above defence sector as shown in Figure 3.

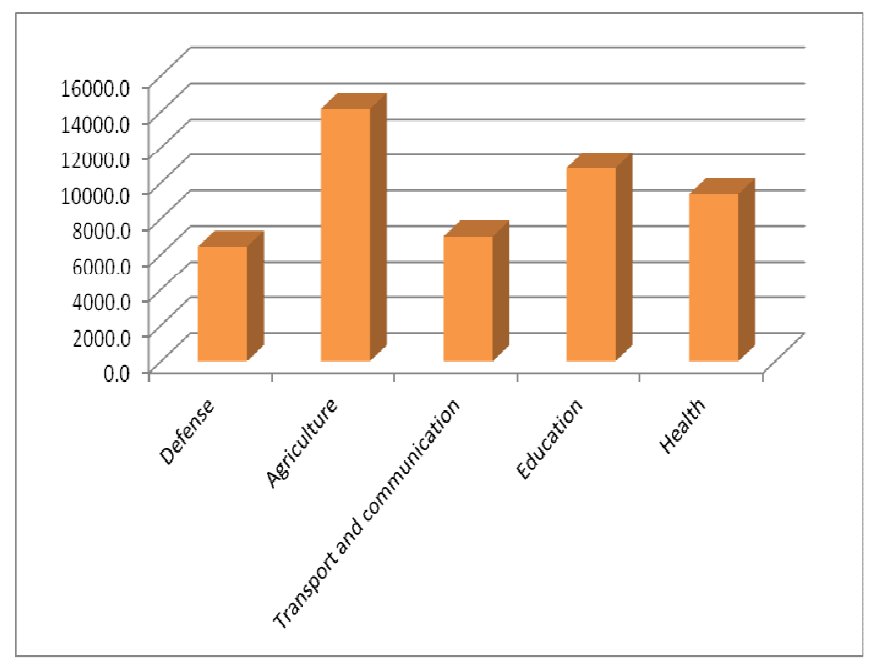

Source: National Bureau of Statistics (2010) [18]

Fig. 3: 1986 - 2007 Average of Federal Government Capital Expenditure by Components (N'million)

\subsubsection{Transport Investment Sectoral Allocation}

Table 2 shows government investment allocation in the different transport modes from 1962 to 2000 . Without doubt, the road transport mode continuously got highest capital expenditure allocation, while the air transport received the lowest. Indeed, the combination of the seaport and the waterways were below the railways during the period under consideration.

Table 2 further demonstrates the continuous heavy concentration of national capital expenditure on road. A vivid examination of the various transport projects since political independence reveals a continued emphasis on transport network that was largely structured on a colonial legacy and emphasis on development of evacuation routes and dominance of roads [19] and [20].

The federal and state governments have always emphasized on road programme by way of substantial investment in new roads since independence. Although, railway transport was still playing an active role in overland freight movement till late 1960, however, from the early 1970 s both the volume of passenger and goods carried by railways started to drop. For instance, passenger traffic dropped from 11.3 million in 1963 to 6.1 million passengers in 1971, while the volume of freight dropped in a steady manner from 2.96 million metric tonnes in 1971, to less than 50 thousand metric tonnes in 2010. 
Table 2: Proportional Allocation of Capital Expenditure to the Transport Sub-Sector 1962-2000

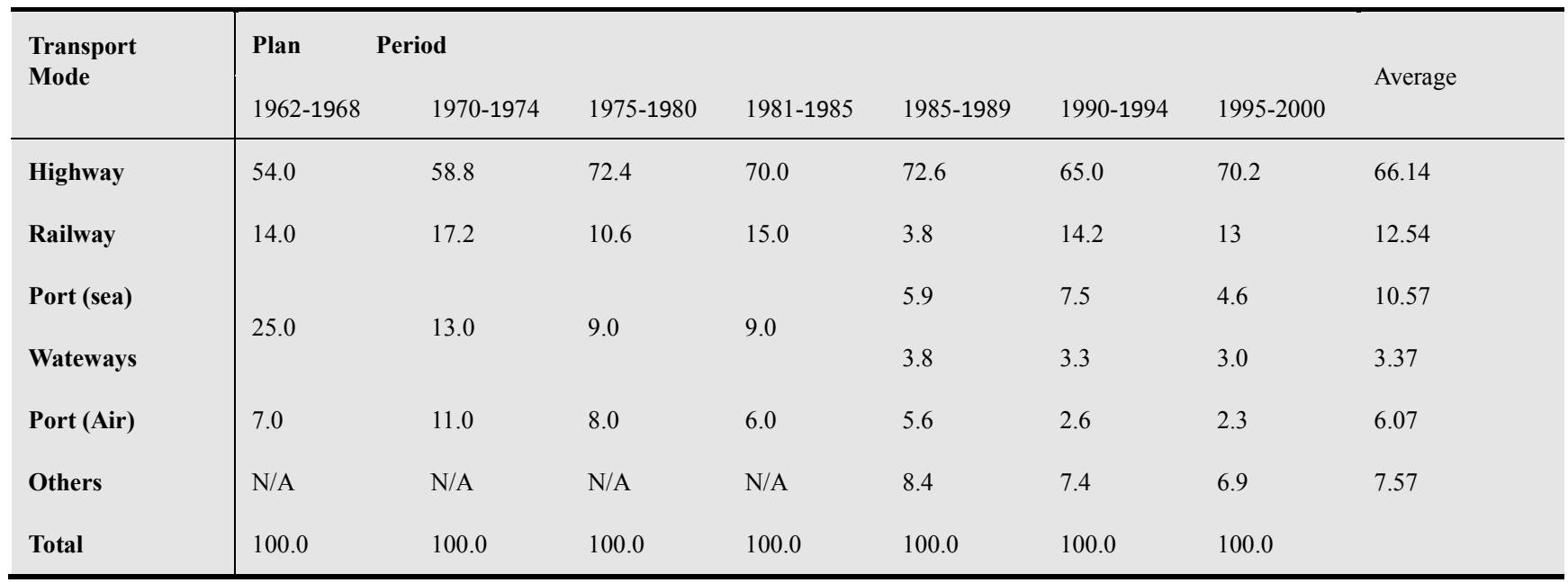

Source: Filani, 2012 [20]

It is important to draw attention to the fact that transport sector in Nigeria has witnessed tremendous and fundamental reforms geared towards creation and developing more focused strategy that can improve productivity of other sectors of the economy and more responsive to demand of users and stakeholders. For instance, concessioning has been adopted in almost all transport sub-sectors, including the Nigeria Railway Corporation, Nigeria Ports Authority, Federal Airport Authority of Nigeria and Inland waterways. In addition, ownership and administration of road transport by Federal and some State governments have been deregulated and some sections of the highway are concessioned to some private concern.

Despite remarkable changes and reforms that are taking place in the development of the transport sector, the transport systems infrastructure in the country remains essentially unimodal as over $95 \%$ of domestic freights and passengers are moved by road.

\section{Literature Review}

Several studies have investigated the impact of infrastructure investment or put differently public capital on economic growth. Many of these studies concentrated on the components of infrastructure investment as the determining factors. This study focuses on the importance of infrastructure investment on economic growth and gives more details to studies that investigate the impact of transport infrastructure investment.

Infrastructure can contribute to output growth either directly or indirectly. Direct contribution is evidenced by studies undertaken by [21] in which he considers a model where public expenditure is productive. Therefore, infrastructure is expected to have a direct effect considering a production function where aggregate output is produced by utilizing capital, labour and infrastructure as production inputs. Likewise, [22] argue that infrastructure provision improves the productivity of private firms and does contribute to output. However, [23] opine that the effect of shock in infrastructural stock would depend on the nature of growth model being investigated, that is, whether an exogenous growth or endogenous growth model. They claimed that in an exogenous growth model, the effect is transitory while in an endogenous growth model, the effect is in most cases results to permanent changes in income per capita.

The indirect channels reveal that beyond the direct inclusion of infrastructure in production function, there is countless transmission channels through which infrastructure can affect growth. Reference [24] and [25] independently considered infrastructure as enhancing indirectly the productivity of workers through reduction in adjustment costs. In similar vein, infrastructure investments impacts through human development, as investment are made on improving health [26] and [27].

Different empirical studies in the past have produced diverse results based on the methodologies used and data employed. Among the earliest empirical studies on infrastructure investment and output growth was [3]. In his study of the G7 countries for the period of 1966 to 1985 (G7 began as a group in 1975 and this study predates the establishment), he employed panel data econometric technique to analyse the relationship between public infrastructure capital and aggregate output of the private sector from a specified Cobb-Douglas function. The result of the study shows how important public infrastructure capital is in explaining aggregate output of the private sector. Reference [11] confirmed the findings of [3] and concluded that coefficient estimates for infrastructure is indeed statistically significant. The results of these two studies illuminate the fact that the productivity slowdown experienced in some countries after 1973 was as a result of poor public capital. However, in response to the results of these two earlier studies, subsequent studies argued that the result estimates lack reality because public capital 
investments have a greater impact on private sector output than private capital investments. Therefore, they concluded that the estimates are likely to have been overstated.

Reference [28] used simultaneous equations approach in their study of 28 metropolitan areas between 1980 and 1984 to establish that local public infrastructure has positive and statistically significant effects on per capita income. Employing the same simultaneous-equation approach as in [28] and [29] examined the contribution of transport infrastructure accumulation to regional growth in France between 1985 and 1992. To eliminate a potential source of bias in the estimates produced by the production function, they modelled the political economy process driving infrastructural investments. Their empirical findings claimed that electoral concerns and influence activities were significant in determining the cross-regional allocation of transportation infrastructural investments. Specifically, there was little evidence that infrastructure spending maximizes economic return. However, [30] in their own study argued that a trans-log function instead of a Cobb-Douglas function produces a better result. They therefore used OLS procedure for estimating the parameters in their model. The result asserts that aggregate public capital has a positive significant relationship to state output. Using the same trans-log function, [6] contend that infrastructure were necessary but not sufficient by themselves to trigger large changes in output.

Using similar technique as [7], but controlling for energy input price and taking into account random effects, [4] in their study of seven OECD countries between 1963 and 1988 came to the conclusion that public investment is significant in determining productivity and growth but its contribution is very low as the output elasticity stood at 0.05 . The observed low output elasticity in [4] can therefore be attributed to the adjustment for energy input price and the account for random effects.

Considering more recent studies, in opposition to earlier studies of partial equilibrium analysis, [31] estimated a general equilibrium model of production and consumption to investigate the U.S. economy. He concluded that public infrastructure is beneficial to firms and consumers, but when there is a significant expansion of infrastructure capital, producers and consumers would be worse off. Reference [32] investigated the Spanish economy from 1850 to 1935 employing Vector Autoregressive (VAR) techniques to study separate infrastructure into local-scope infrastructural investment and nationwide infrastructure investment. The conclusion was that local-scope infrastructure impact was positive and significant, but nationwide infrastructure was insignificant. Reference [26] in their study of China between 1986 and 2005 investigated the effect of access to transportation network on regional demographic and economic outcomes. They compared the estimates of OLS to 2SLS to analyse the study's objective. The result of the study establish that proximity to transportation networks have a large positive causal effect on per capita GDP growth rates across sectors. The comparison between OLS and 2SLS showed that the 2SLS estimates were larger in magnitude and much noisier than the OLS estimates.

With respect to the effect of transport investment on economic growth in developing countries, [33] investigated the contribution of transport capital to growth for a sample of Sub Saharan African (SSA) countries from 1980 to 2000 and also for Small Island Developing States (SIDS) from 1985 to 2000 using both cross sectional and panel data analysis. In both sample cases, the study argued that transport capital has been a contributor to the economic progress of the countries under investigation. Furthermore, he observed that transportation capital have been more productive than the overall capital investment in SSA case, whereas it was observed to have the average productivity level of overall capital stock in SIDS case. In another study by [13] of 33 African countries for the period of 1980 to 2002, findings show that transport capital is an important element for development and that there exists a bi-causality relationship between transport capital and economic growth.

At the local level in Nigeria, some of the studies carried out including that of [34], [35] and [36] showed that transportation expenditure has a significant effect on output growth. Reference [35] adopted an extended Cobb-Douglas production function and an OLS estimation technique to investigate the Nigerian economy between 1980 and 1997. The result shows that all the six infrastructural components are directly related with GDP. The study by [36] demonstrates that for Nigeria to attain or surpass average growth rates of Asian countries, contribution of infrastructure to GDP has to increase by a factor of 9 in "tangible" spending (i.e. from $1.9 \%$ to $18 \%$ per annum) over 15 years; and to achieve that over 10 years, it will require increased infrastructure spending by a factor of 12 (i.e. from $1.9 \%$ to $24 \%$ ) per annum. He therefore advocated for the need for urgent reform programmes that will enhance infrastructure development if really the country's vision 2020 programme is to be realised.

In the light of the foregoing review, it seems that the literature is inconclusive on the effect of infrastructural investment on economic growth. In particular, few studies exist on the impact of transport infrastructural investment on output performance, particularly with reference to Nigeria. The intention thereof of this study is to fill this gap in research.

\section{Analytical Framework and Methodology}

\subsection{Analytical Framework}

There are two basic discernible primary benefits an economy can derive from an improved transportation system. These benefits are reduced transportation cost and increased accessibility. Given these benefits, it is expected that transportation will impact economic growth directly and indirectly (through other avenues) as the case may be. According to [37], in the cost benefit analysis (CBA) of 
transportation investment, the direct user benefits of travel time, reduced vehicle operating cost and safety are mainly considered. In addition, transport infrastructure investments have social-economic spill-over which is referred to as the indirect impacts - reorganization and rationalization of production, better productivity and higher level of private (inwards and foreign direct) investment, wider markets, increased specialization and economies of scale. Transport investments also have effects on labour market supply, labour costs and labour productivity [13].

The channels through which transport infrastructure investment affects output and economic growth is summarised by [13] as adapted in Figure 4, indicating that transport infrastructure investment has direct primary effects on intermediate input cost and provides increased accessibility. This in turn leads to relocation and agglomeration effect, increase efficiency of private capital, attraction of inward and foreign direct investment, provides wider markets, produces labour market and employment effects. All these effects ultimately lead to improved aggregate productivity, hence, enhance economic growth.

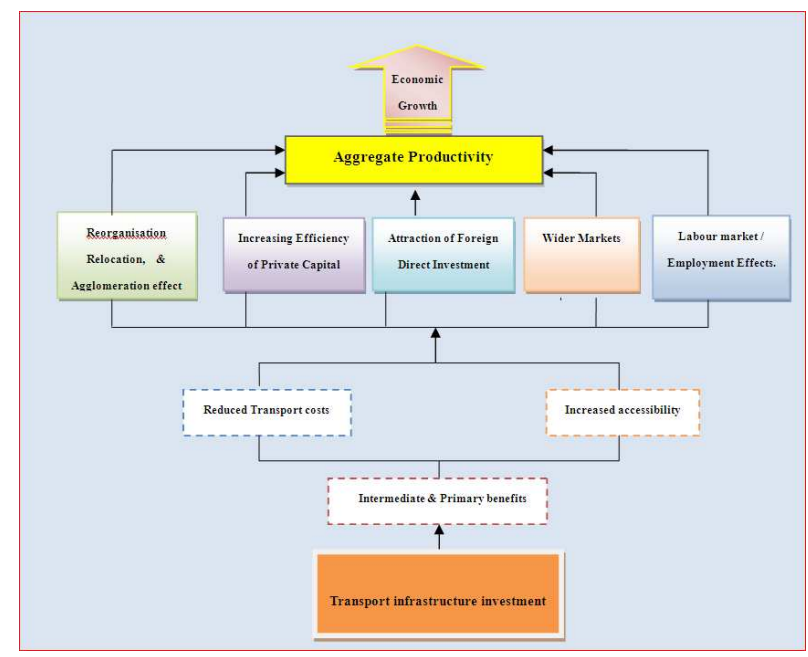

Source: Adapted from Seetanah (2009) [13]

Fig. 4: Transmission Channel between transport infrastructure investment and economic growth

Given the above, a number of theoretical expositions that demonstrate the linkages between infrastructural capital (transport) investments and economic growth have been provided in the literature. The linkage often discussed in this context take the form of the following labour augmenting model.

$$
Y(t)=F[K(t), A(t) L(t)]
$$

The above model assumes that at any point in time, the economy has some amount of capital $(K)$, labour $(L)$ and knowledge or effectiveness of labour $(A)$, and these are combined to produce output $(Y)$. From the production function, ' $t$ ' denotes time which does not enter the production

function directly but through capital, labour and knowledge. That is, output changes overtime only if the inputs to production change. In particular, the amount of $Y$ obtained from given quantities of $K$ and $L$ rises over time. The model assumes that there is technological progress only if the amount of $A$ increases.

Because we are interested in investigating the determinants of growth, that is, how much of growth over some period is due to increases in various factors of production, and how much stems from other forces; growth accounting which was pioneered by [14] and [15], provides a basis for exploring the issue.

From equation (1), the growth of output can be represented as

$$
\dot{Y}(t)=\frac{\partial Y(t)}{\partial K(t)} \dot{K}(t)+\frac{\partial Y(t)}{\partial L(t)} \dot{L}(t)+\frac{\partial Y(t)}{\partial A(t)} \dot{A}(t)
$$

where the dot over a variable denotes a derivative with respect to time; that is $\dot{O}(t)=\partial O(t) / \partial(t)$. Dividing both sides by $Y(t)$ and rewriting the terms on the right hand side yields:

$$
\frac{\dot{Y}(t)}{Y(t)}=\frac{K(t)}{Y(t)} \frac{\partial Y(t)}{\partial K(t)} \frac{K(t)}{K(t)}+\frac{L(t)}{Y(t)} \frac{\partial Y(t)}{\partial L(t)} \frac{\dot{L}(t)}{L(t)}+\frac{A(t)}{Y(t)} \frac{\partial Y(t)}{\partial A(t)} \frac{\dot{A}(t)}{A(t)}
$$

where $\dot{O}(t) / O(t)$ is the growth rate of $O$ which refers to its proportional rate of change. Equation (2) is rewritten as follows:

$$
\frac{\dot{Y}(t)}{Y(t)}=\alpha_{K}(t) \frac{\dot{K}(t)}{K(t)} \cdot \alpha_{L}(t) \frac{\dot{L}(t)}{L(t)}+R(t)
$$

where:

$\alpha_{K}(t)=[K(t) / Y(t)][\partial Y(t) / \partial K(t)]$ is the elasticity of output with respect to labour $(L)$ at time $t, \alpha_{L}(t)=[L(t) / Y(t)][\partial Y(t) / \partial L(t)]$ is the elasticity of $Y$ with respect to $K$, and

$R(t)$ represents $\left.{ }_{[A(t)} / Y(t)\right][\partial Y(t) / \partial A(t)][A(t) / A(t)]$ which can be measured as residual in the equation. Finally, equation (3) provides a way of decomposing the growth of output into the contribution of growth of capital, growth of labour and residual.

\subsection{Empirical Model and Data}

Following from the above analytical framework, a variant of augmented Solow model econometric framework employed in the study by [13] is adopted in this study. We decomposed capital investment into three types, namely private capital, transport and other public capital investment. Thus, the relationship among variables of interest in this study is presented in equation (4).

$$
Q=f(\text { Pinv }, \text { Trans }, \text { Opinv }, E d u)
$$

Where $Q$ represents total output measured by the gross domestic product, Pinv is the private physical capital, Trans represents transportation capital, Opinv is the other public capital investment, and $E d u$ is the secondary school enrolment which accounts for the quality of labour.

Equation (4) is further transformed into an empirical 
econometric model by taking the growth of all the variables under investigation and adding the error term, thus, we have:

$$
\begin{aligned}
& Q_{1}=\beta_{0}+\beta_{1} \text { Pin } y+\beta_{2} \text { Trans }+\beta_{3} \text { Opin } y+\beta_{4} E d u+\mu_{t}, \\
& \beta_{1}, \beta_{2}, \beta_{3}, \text { and } \beta_{4} \succ 0
\end{aligned}
$$

Equation (5) shows that the a priori expectation states that the elasticity parameters $\beta_{1}$ to $\beta_{4}>0$, which implies that all the variables are expected to have a direct relationship with total output. This explains that as private investment, transportation capital, other public capital investment, and quality of labour increase, output also increase and vice versa. $B_{0}$ is the constant term and $u_{t}$ is the stochastic term representing other variables not included in the model but which affect the level of output.

In order to arrive at a reliable estimate of the elasticity parameters, this study investigates the unit root properties of the variables under study using the Augmented Dickey Fuller, ADF (1979) Test. Finally, all the variables are in real terms except education $(E d u)$. The data for the study are mainly secondary and cover the period from 1977 to 2009 . The study does not extend beyond 2009 due to none availability of the data for all the variables after 2009 . The data are sourced from the [38], [18] and [39].

\subsection{Estimation and Discussion of Results}

The results of empirical analysis carried out in the study are presented in Tables 3, 4, and 5 which include the time series test and the regression results. As a prelude to the regression analysis, Granger causality test is carried out on the surface assessment of the direction of effect between transport infrastructure investment and growth. The result of the test given in

Table 3: Pairwise Granger Causality Tests

\begin{tabular}{llll}
\hline Null Hypothesis: & Obs & F-Statistic & Probability \\
\hline $\begin{array}{l}\text { TRANS does not Granger Cause } \\
\text { Output }\end{array}$ & 0.04890 & 0.82659 \\
Output does not Granger Cause TRANS & 0.18454 & 0.67079 \\
\hline
\end{tabular}

An important consideration often ignored by past studies before estimation is to test if the variables under investigation are stationary or not. As a result, we carry out unit root tests on all the variables of the model to test for the null hypothesis of non-stationarity. Using the Augmented Dickey Fuller (ADF) test, the unit root result as shown in Table 4 however indicates that all the variables of the model are stationary at their original level, that is, they are integrated of order one $\mathrm{I}(0)$. This implies that the deviation around their mean values is zero. A closer look at the results show that the stationary levels of the variables range between 5 per cent and 1 per cent.
Table 4: Results of Unit Root Tests

\begin{tabular}{llllll}
\hline \multirow{2}{*}{ Variable } & \multicolumn{2}{l}{ Without Trend } & With Trend & & $\begin{array}{l}\text { Order of } \\
\text { Integrat } \\
\text { ion }\end{array}$ \\
& Level & First Diff & Level & First Diff & \\
\hline Output & $-3.00^{* *}$ & $-8.71 * * *$ & $-4.03 * *$ & $-8.56 * * *$ & $\mathrm{I}(0)$ \\
Pinv & $-5.45^{* * *}$ & $-7.84 * * *$ & $-5.98^{* * *}$ & $-7.68 * * *$ & $\mathrm{I}(0)$ \\
Trans & $-3.17 * *$ & $-6.12 * * *$ & $-3.44 *$ & $-6.02 * * *$ & $\mathrm{I}(0)$ \\
Opinv & $-5.22 * * *$ & $-7.69 * * *$ & $-5.12 * * *$ & $-7.61 * * *$ & $\mathrm{I}(0)$ \\
Edu & $-3.24 * *$ & $-9.44 * * *$ & $-3.37 *$ & $-10.86 * * *$ & $\mathrm{I}(0)$ \\
\hline
\end{tabular}

Notes:

$*, * *$ and $* * *$ implies significance at $10 \%, 5 \%$ and $1 \%$ level respectively. Critical Values for ADF tests are the following:

- In the model without trend: Level form:

$-3.6661(1 \%),-2.9627(5 \%)$ and $-2.6200(10 \%)$

First difference: $-3.6752(1 \%),-2.9665(5 \%)$ and $-2.6220(19 \%)$

- In the model with trend: Level form:

$-4.2949(1 \%),-3.5670(5 \%)$ and $-3.2169(10 \%)$.

First difference: $-4.3082(1 \%),-3.5731(5 \%)$ and $-3.2203 \quad(10 \%)$.

In the regression analysis, the growth rates of all the variables are used. Since all the variables are $\mathrm{I}(0)$, this implies that coefficient estimates obtained from using such data will be unbiased when OLS technique is employed. Various estimations of the empirical model are performed; however, the estimation that yielded the best result is reported in Table 5. The result indicates that the effect of transportation investments is of little relevance in determination of output growth. Specifically, the result indicates that there exists an insignificant positive relationship between growth in transportation investment and growth rate of GDP in Nigeria. Specifically, a unit increase in transportation infrastructure investment over two previous periods will result in a marginal rise of 0.003 units in output.

Despite the insignificant impact, the positive relationship implies that as public sector transportation investment increases over time, output tends to rise. The insignificant relationship between the transportation investment and growth can be adduced to continuous decline in government expenditures in the transport sector relative to other sectors in Nigeria over the years (as noted in Figure 3). Reference [34] noted that the economic downturn of the 1980s which resulted from the oil glut coupled with the huge external debt that led to the adoption of the structural adjustment programme (SAP) in 1986 caused contraction of the public sector and reduction in its spending.

All other variables in the model exhibit the a priori expectations (positive relationship) in terms of their signs, except education $(E d u)$ that exhibits a negative but significant relationship with output growth. Private investment (Pinv) has a significant positive relationship with output growth, indicating the importance of other forms of private investment in stimulating growth. Other public investment (Opinv) have a weak significant positive 
relationship with output growth. Although transportation investment is highly insignificant in the model, all the variables of the model are jointly significant in determining variations in GDP as the F-statistics stood significant at one per cent level. However, their explanatory power is weak as $\mathrm{R}^{2}$ stood at 0.5553 . Finally, the Durbin-Watson (DW) statistic shows the absence of autocorrelation in the model as it stood at 1.6414 and greater than $\mathrm{R}^{2}$.

Table 5: OLS Regression Results

\begin{tabular}{llll}
\hline Variable & Coefficient & t-Statistic & Probability \\
\hline $\mathrm{C}$ & 3.8614 & 5.1547 & 0.0000 \\
Inv & 0.0630 & 2.0295 & $0.0532^{*}$ \\
Trans(-2) & 0.0033 & 0.8645 & 0.3955 \\
Opinv & 0.0320 & 1.7822 & $0.0869^{*}$ \\
Edu(-1) & -0.1290 & -4.4204 & $0.0002^{* * *}$ \\
$\mathrm{R}^{2}=0.5553$ & & & \\
D.W. $=1.6414$ & & \\
F-statistic $=7.8029$ & & \\
Prob(F-statistic) $=0.0003$ & & \\
\hline
\end{tabular}

*, *** indicate 10 percent and 1 percent significance level respectively

\section{Conclusion}

The development of transportation system is very often regarded as significant for the economic development of a country; as transportation investment has both direct and indirect effects on the economy. Consequently, this study has examined the impact of transportation capital investment on economic growth in Nigeria between 1977 and 2009. The empirical analysis was carried out by employing the Ordinary Least Square (OLS) estimation technique.

The findings of the study suggested that transportation is insignificant in determining economic growth in Nigeria. However, because of the positive relationship between transport and economic growth, more public funding and complete overhauling of the transportation system is hereby recommended. This would ensure the resuscitation of the degrading status of the transportation system and enhance its role in the process of economic growth.

The conclusion of this paper seems inevitable going by the low level of investment of transport infrastructure within the nation's economy. This trend is not unconnected with the challenges of transport development in the country. In the first instance, there is no discernible transport policy for the country even though there has been recommendations for the various modes based on various studies but where not implemented. Indeed, there were whitepaper recommendations on national transport policy documents of 1993 and 2004, both explaining the crisis in the Nigerian transport sector and the inability of the transport system in the country to meet the transport demands of Nigerian economy. The need to have remarkable increase in the investment on transport infrastructure is therefore not unconnected with the state of the transport modes. Specifically, in respect of the five major modes of transport in the country, the pipeline transportation is plagued by old and corroded pipes and frequent fire outbreaks arising from illegal tapping of pipelines products. For railway infrastructure, the composite of the railway system is outdated, obsolete and indeed, no longer functional. The network does not connect to major resources and activity centres of the country. In addition, the speed is slow and the operational schedule extremely unreliable. The old substandard gauge is still pervasive across the country, with the concomitant sharp curves and step gradients. Perhaps, more importantly, there is poor connectivity of the railways with roads, seaports and waterways, which therefore makes integration with other modes virtually nonexistent.

Inland waterways and the ports also have their challenges as most rivers has have excessive falls and rapids, and are seasonal. The seaports have witnessed stagnated development for several years due in-part to various previous economic strategies, particularly the structural adjustment programme that ensured that import dependency option persisted for so long. This existed during this period and up till 2006 when the national government embraced best practices of port reforms and improved their administration and management by concession to private investors to ensure development of the Nigerian seaports system is consistent with increasing investment.

Airways and aviation transportation for some time, as well, had limited investment despite increasing air travel demand, enhanced standard of living and improved economy. There was heavy investment of air transportation up till the late $1980 \mathrm{~s}$, which witnessed physical infrastructural development of airports in virtually every of the then twenty-one states of the federation. However, most of these airports are not functional and the capacity utilization of most of them extremely low [40]. The main reason for this low capacity utilization was simply because the investments in air transportation, particularly the development of airports was basically political rather than being utilization demand driven. The road transport has been over used and misused given the fact that it has received the greatest attention of the government at all levels since the early 1970 s to the mere neglect of other modes and to the detriment of intermodal connectivity and transportation systems. Despite the investment favouring road transport system, the network is still beleaguered by poor quality of road construction, faulty and inappropriate designs, poor supervision of construction work, and inadequate administrative capacity for maintenance. The over-burdened road transport system is also characterized by proportionally high road traffic accidents.

In the light of these undoubting challenges, it is expected that investment in transport infrastructure would be commensurate with the desire to redress them, because of the implications for commodity flow, regional trade, and economic development of the country. The policy outlook perhaps is to have greater public investment in transport sector so as to contribute significantly to the economic development and growth of the country. The major areas of 
the directional policy shift should be the rehabilitation and a fresh reconstruction of railway infrastructure that could link various parts of the country and greater investment on transport infrastructure generally. Going by the extent of decay of road transport infrastructure (poor quality roads and lack of effective traffic management and enforcement), greater investment in road sector is imperative to improve maintenance, repairs and rehabilitation of the roads to reduce further deterioration of the road network. Increasing funding of the sector will also enhance capacity building to enforce existing regulations, traffic management measures, improve vehicle inspection and general improvement of service quality of the transport mode in the country. Furthermore, there must be a greater private sector participation, particularly in the air transport and seaport development. The support of public capital investment to compliment the private sector participation in modern transport system of the country cannot be over emphasized. The notable development of the maritime sector through concession of the seaport and strengthening public-private partnership must be encouraged. The air transportation subsector must be further deregulated to accomplish the incredible increase in the activities of the private airlines in the operation in the country.

There is need for effective co-ordination among the national, state and local levels, on capital investment of transport projects. The benefits of transport investment are immeasurable to all. However, transport investment by all levels of government has been disjointed; while the economic development benefit effects have been seen purely from political standpoint. Indeed, many transport development investment projects have not been properly quantified, and in many cases never passed through budgetary allocation process because they are done haphazardly. Without doubt, transport investment would not only generate accessibility and other transport benefits - it will enhance overall regional economic development.

\section{Acknowledgements}

Acknowledgement: The authors gratefully acknowledge the excellent research assistance from Adedokun, Adeniyi . However, the usual captive emptor prevails.

\section{References}

[1] von, F. Hayek, "The Pure Theory of Capital" 1941, 1950 edition. University of Chicago Press, Chicago.

[2] T. Haavelmo, "A Study in the Theory of Investment," University of Chicago Press, Chicago, 1960.

[3] D.A. Aschauer, "Is public expenditure productive?," Journal of Monetary Economics, vol. 23, 1989a, pp. 167 200.

[4] F. Nourzad, and M. Vrieze, "Public capital formation and economic growth: Some international evidence," Journal of Productivity Analysis, vol. 6 (4), 1995, pp. 283-295.
[5] D. Canning, "Infrastructure's contribution to aggregate output", World Bank Policy Research Working Paper, No. 2246, Washington, D.C., 1999.

[6] D. Canning, and E. Bennathan, "The social rate of return on infrastructure investments", World Bank Research Project, RPO 680-89, Washington, D.C., 2000.

[7] D.A. Aschauer, "Does public capital crowds out private capital?", Journal of Monetary Economics, vol. 24, 1989b, pp.171-188.

[8] M. B. Ortiz-Moctezuma, D. Pivovarchuk, J. Szolgayova and F. Sabine, "Development of transportation infrastructure in the context of economic growth," 2010', Retrieved from www.iiasa.ac.at/Research/ECG/target-seminars/ecg_08/Moc tezuma.pdf

[9] F. Rodriguez, "Have collapses in Infrastructure Spending led to Cross-country Divergence in per Capita GDP? A Century Foundation Report," Century Foundation, New York. 2010.

[10] A. H. Munnell, "Why Has Productivity Declined? Productivity and Public Investment," Investment, Federal ReserveBank of Boston. Boston, 1990.

[11] A.H. Munnell, "Policy watch: Infrastructure investment and economic growth," Journal of Economic Perspectives, vol. 6(4), 1992, pp. 189-198.

[12] T. H. Oum, W.G. Waters and Y. Chunyan, "Development of an econometric model linking public transportation investments to economic growth in British Columbia," The Centre for Transportation Studies, The University of British Columbia, British Columbia, 1998.

[13] B. Seetanah, "Using GMM framework to analyse the role of transport infrastructure in economic growth: The African case," Paper Presented at the 9th Global Conference on Business and Economics. 2009.

[14] M. Abramovitz, "Resources and output trends in the United States since 1870," American Economic Review, vol. 46, May, 1956, pp. 5-23.

[15] R. M. Solow, "Technical change and the aggregate production function," Review of Economics and Statistics, vol. 3 (3), 1957, pp. 312-320.

[16] K. Haynes, and K. Button, "Transportation systems and economic development," in Button, K. J. and D. A. Hensher (eds.) Handbook of Transport Systems and Traffic Control, Elsevier Science Ltd., London, 2001, pp. 255- 268.

[17] P. C. Onokala, "Transport systems in nigeria', Lead Paper presented at the International Colloquium on Thirty Years of Social Services and Management in Nigeria, in honour of Professor Emeritus Andrew Onokerhoraye, at Precious Palm Royal Hotel, Benin City, Nigeria, 26th - 28th March, 2012.

[18] National Bureau of Statistics (2010), Retrieved from:http//www.nigerianstat.gov.ng /index.php//sectorStatistics

[19] B. Odufuwa, J. Fransen, A. Bongwa and A. Gianoli, "Cities, theories and reality," Journal of Geography and Regional Planning, vol. 2 (10), 2009, 243-248.

[20] M. O. Filani, "Transport systems in Nigeria," Lead Paper 
presented at the International Colloquium on Thirty Years of Social Services and Management in Nigeria, in honour of Professor Emeritus Andrew Onokerhoraye, at Precious PalmRoyal Hotel, Benin City, Nigeria, 26th - 28th March, 2012.

[21] R.J. Barro, "Government Spending in a Simple Model of Endogenous Growth," Journal of Political Economy, vol. 98, 1990, pp. 103-125.

[22] C.J. Morrison, and E. Schwartz, "State infrastructure and productive performance", American Economic Review, 86, 1996, pp. $1095-1111$

[23] D. Canning, and P. Pedroni, "Infrastructure and long-run economic growth", Working Paper No. 99-09, Centre for Analytical Economics, Cornell University, New York., 2004.

[24] S. J. Turnovsky, "Fiscal policy, growth, and macroeconomic performance in a small open economy," Journal of International Economics, vol. 40(1-2), 1996, pp 41-66.

[25] P-H. Agénor, and J. Aizenman, "Investment and deposit contracts under costly intermediation and aggregate volatility," International Review of Economics and Finance, vol. 15(3), 2006, pp. 263-275.

[26] A. Brenneman, and M. Kerf, " Privatizing Africa's infrastructure: Promise and challenge," World Bank Technical Papers, vol. 337, 2002.

[27] E. Helpman, "The Mystery of Economic Growth," Harvard University Press, Cambridge. 2004.

[28] K. T. Duffy-Deno, and R. W. Eberts, "Public infrastructure and regional economic development: A simultaneous equations approach", Journal of Urban Economics, vol. 30, 1991, pp. 329-343.

[29] O. Cadot, L. Roller and A. Stephan, "Contribution to Productivity or Pork Barrel? The Two Faces of Infrastructural Investment", Journal of Public Economics, vol. 90, 2006, pp. 1133-1153.

[30] R. Moomaw, J. Mullen and M. Williams, "The interregional impact of infrastructure capital", Southern Economic Journal, 1995 , pp. 830-848.

[31] A. Haughwout, "Public infrastructure investments, productivity and welfare in fixed geographic areas," Journal of Public Economics. vol. 83, 2002, pp. 405-425.
[32] A. Herranz-Lonca'n, "Infrastructural Investment and Spanish Economic Growth: 1850-1935," Explorations in Economic History, vol. 44, 2007, pp. 452-468.

[33] B. Seetanah, "Transport infrastructure and economic growth: Evidence from Africa using dynamic panel estimates," The Empirical Economics Letters, vol. 5(1), 2006

[34] L.A. Amaghionyeodiwe, and A. O. Folawewo, "Government investment policy on transport and economic growth: The Nigerian experience," Nigerian Economic Society: Rekindling Investment for Economic Development in Nigeria, 1998, pp. 243-255.

[35] B. E. Aigbokan, "Evaluating investment on basic infrastructure in Nigeria", Proceedings of the Eighth Annual Conference of the Zonal Research Units . Organised by Research Department, Central Bank of Nigeria, at Hamdala Hotel, Kaduna, 11 -15 June, 1999.

[36] M. Akinyosoye, "Infrastructure development in Nigeria road map to sustainable development", Working Paper. Green Hill Technical Services Ltd, Lagos, 2010, Retrieved from resource.management6.com/Sustainable-development-pdf.

[37] Organisation for Economic Co-operation and Development, OECD," Impact of transport infrastructure investment on regional development," OECD Publications, Paris. 2002.

[38] Central Bank of Nigeria (2010). Statistical Bulletin Retrieved from www.cenbank.org/OUT/2011/ PUBLICATIONS/STATISTICS/2010/PartB/PartB.html

[39] World Bank (2011). List of economies.World Development Indicators. Washington DC, 11. Retrieved from: $\mathrm{http} / /$ siteresources.worldbank.org/DATASTATISTICS/ Resources /CLASS.XLS

[40] O. K. Oyesiku, and W. Oduwole, "Determinants of distribution of investment infrastructure: The case of spatial distribution of airports in Nigeria", Paper presented at the 8th International World Conference of the Air Transport Research Society, on Emerging Roles of Major Airports in Airports in Air Transport System and Economy held at Istanbul Technical University, Istanbul, Turkey, 1st - 3rd July, 2004. 